\title{
Tourist Behavior of Plastic Waste Reduction in the Coastal Area of Trang Province, Thailand
}

\author{
Weerawat Ounsaneha, Orapin Laosee, Thunwadee Tachapattaworakul Suksaroj, Pintip Srisamai, and \\ Cheerawit Rattanapan
}

\begin{abstract}
The objective of this study is to estimate the tourist behavior of plastic waste reduction in the coastal area of Trang Province, Thailand. 316 tourists (153 male, 163 female) traveling in the five districts along with the coastal area were included as the participants in this study. The results showed that $57 \%$ of the tourists were found to be good behavior. Amongst 14 variables in statistic analysis, knowledge was found as significant predictor after adjusting in full model of multiple logistic regression. The knowledge compain of plastic waste reduction ought to be promoted to increase of awareness among tourists for reducing plastic waste problem in the coastal area at early age. A greater emphasis must be placed on formulation and implementation of policies aimed at addressing the emerging problems of plastic waste in the costal area of Thailand.
\end{abstract}

Index Terms-Tourist behavior, plastic waste reduction, coastal area, Thailand.

\section{INTRODUCTION}

Over the past decades, plastic consumption has increased exponentially and leaded to parallel growth in mismanaged plastic waste [1], [2]. It is almost completely non-degradable and fragmented into microplastics in the marine environment [3], and as evidence of its hazards increases [4], greater attention is required to address this problem [5]. Trotter et al. [6] mentioned that plastic waste has direct negative effects on animals such as reduced growth rate, fecundity or life span. However, the indirect effects of plastic waste, which has the ability to sorb chemicals from the surrounding media, on chemical communication have yet to be investigated. Its impact is of global significance, and the threats posed by marine litter to humans and the environment have been recognized for around 58 years [7]. However, despite its importance, it has only gained real recognition during the past few years.

Presently, the plastic waste issue is a problem that has grown out of hand. Its costs to society and marine environments are immeasurable and irreversible. Its impact encompasses local, regional, national, and global scales and includes adverse effects on human health, aesthetics, the

Manuscript received October 12, 2019; revised February 25, 2020

Weerawat Ounsaneha is with Faculty of Science and Technology, Valaya Alongkorn Rajabhat University under the Royal Patronage, Thailand (e-mail: weerawat@vru.ac.th).

Orapin Laosee, Thunwadee Tachapattaworakul Suksaroj, and Cheerawit Rattanapan are with ASEAN Institute for Health Development, Mahidol University, Thailand (e-mail: orapin.lao@mahidol.ac.th, thunwadee.suk@mahidol.ac.th, cheerawit.rat@mahidol.ac.th).

Pintip Srisamai is with Trang Provincial Administrative Organization, Trang, Thailand (e-mail: pintipkwan@gmail.com). economy, public perception and and biologic interactions [8]. It can have land-based (e.g., direct from rivers and beaches, which is where the bulk comes from) as well as sea-based sources (e.g., waste disposal from shipping, oil rigs) [9]. Lebreton et al. [10] compiled the International Coastal Cleanup results as 'Shoreline and recreational activities' comprised 57\%, 'Ocean and waterway activities' $6 \%$, and the other 3 sources like 'Smoking activities' 37\%. Based on the assessment that marine debris is rapidly accumulating in the center of the oceans, it is important to reduce solid waste inputs into the sea.

Trang Province locates in the Southern part of Thailand with approximately 119 kilometers of 5 districts for costal area. According to the data on tourist profile by the end of 2016, the tourist number and revenue are the third and fourth orders of Southern part of Thaliand, respectively [11]. From the report of Trang Provincial Administrative Organization [12] reported that more than 240,621 tons of total solid waste was generated in 2017. The low efficiency of solid waste management including separation, collection, transportation processes was presented in Trang province. Hence, there are the high chance of being able to enter the beach and the sea.

The transformation of a region into a tourist destination causes changes in socio-spatial relationships, leading in many situations to the disfigurement of natural landscapes and environmental degradation. Silva et al. [13] indentified that the lack of education of the tourists and beaches users, who throw away the garbage produced by them on the sands of the beaches. The educational efforts such as signs at the entrance of the beaches, educational campaigns on a local or national scale, beach-cleaning activities to reduce the waste; increase the cleaning frequency on beaches; strengthen law enforcement in coast areas; reduce the use of disposable items on the coastal area should be recommenced [14], [15].

This study was to evaluate the tourist behavior of plastic waste reduction in the coastal area of Trang Province, which is the one of the many tourist coastal area of Thailand. Firstly, the plastic waste reduction of tourist behavior in five district of coastal area in Trang province was to explore. The association and best predictor of tourist behavior for plastic waste reduction were investigated by logistic regression and multiple logistic analyses, respectively.

\section{MATERIAL AND Methods}

\section{A. The Study Area}

Data for this research was collected by developed questionnaire focusing on plastic use reduction among Thai 
tourists in the coastal area of Trang Province, Thailand. Five districts in the coastal area of Trang Province including Sikao, Kantrang, Yan Ta Khao, Hatsam ran and Palian were included as the study area. Fig 1 shows a map of the coastal area of Trang Province, Thailand. The data based on the developed questionnaire was collected during March -May 2019 after approving by Committee for Research Ethics, Mahidol University (COA. No. 2019/122.2105). A total of 316 respondents were included in this study. The target population in this study was the tourist in five districts of the coastal area of Trang Province. Tourists completed a questionnaire through face to face interview. Likewise, simple random sampling was used to select 316 tourists from each district.

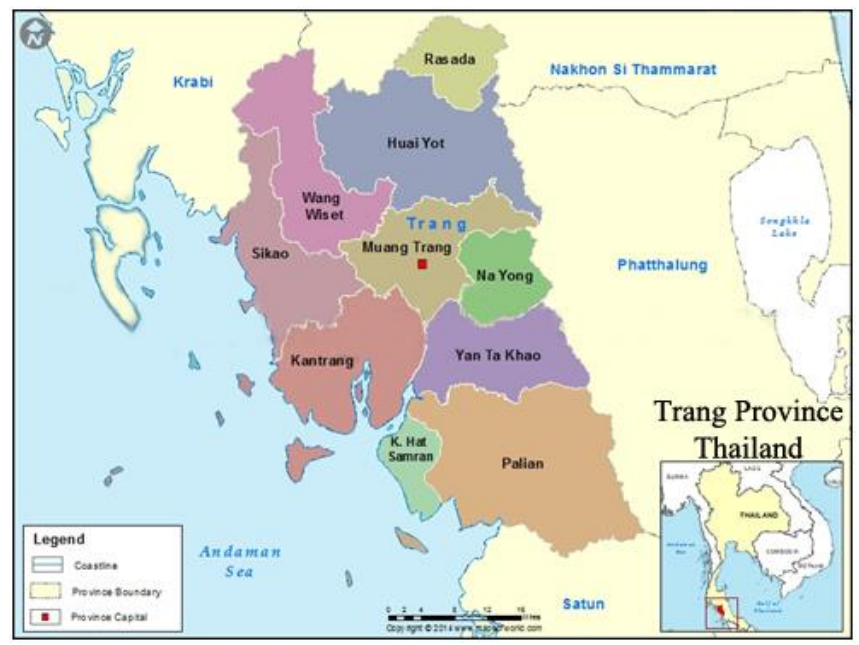

Fig. 1. A map of the coastal area of Trang province, Thailand.

\section{B. Questionnaire}

Structured questionnaire based on the literature review was used in the study. This questionnaire was divided in four parts; demographic characteristics; knowledge of plastic waste reduction; altitude of plastic waste reduction; and behavior of plastic waste reduction. Tourist behavior of plastic waste reduction and predictor factor were determined. Reliability tests for the attitude part gave a value of 0.65 for Conbach's Coefficient-Alpha.

\section{Data Management and Statistical Analysis}

The results are described by means of central tendency for each variable. In addition, the associations between behaviors of plastic waste reduction with independent variables were analyzed by chi-square tests. In addition, the independent variables with a p-value $<0.25$ in bivariate analysis were included in the full model of multiple logistic regressions along with their $95 \%$ confidence interval. All the analysis was performed by using IBM SPSS V 20.

\section{RESULT AND DISSCUSSION}

\section{A. Characteristic of Tourist}

Acorrding to the data from the questionaires (Table I), more than $51 \%$ of tourists in this area were female. The majority of tourtists $(46.8 \%)$ were bachelor degree and above for education background. Most of them (60.1\%) were in the married status. More than $27.5 \%$ of tourists have the own business with more than 15,000 Baht (27.8\%) for monthly income. Concerning the residency profile, over $60 \%$ of tourists were stayed in this province with third time visit $(28.5 \%)$. The main propose $(58.9 \%)$ of visit from tourist were leisure with one day trip $(66.1 \%)$. Most tourist involvement and motivation in this province on the plastic reduction were reduce plaster used $(41.1 \%)$ and community commend $(44.9 \%)$, respectively

TABLE I: DEMOGRAPHIC INFORMATION OF PARTICIPANTS $(N=316)$

\begin{tabular}{lcc}
\hline \hline Items & Number & Percent \\
\hline Sex & 153 & 48.4 \\
$\quad$ Male & 163 & 51.6 \\
$\quad$ Female & 1 & \\
Education & 57 & 0.3 \\
$\quad$ No school & & 18.0 \\
$\quad$ Primary school & 110 & 34.8 \\
Secondary & 148 & 46.8 \\
$\quad$ school & &
\end{tabular}

Status

Single 106

$\begin{array}{lll}\text { Married } & 190 & 60.1\end{array}$

Divorce $\quad 18 \quad 5.7$

$\begin{array}{lll}\text { Widow } & 2 & 0.6\end{array}$

\begin{tabular}{lcc}
\hline \hline Items & Number & Percent \\
\hline Occupation & 87 & 27.5 \\
Own business & 75 & 23.7 \\
Employee & 49 & 15.5 \\
Farmer & & \\
Government & 38 & 12.0 \\
officer & 43 & 13.6 \\
Private office & 10 & 3.2 \\
Housewife & 14 & 4.4 \\
Student & & \\
Income (Baht) & 25 & 7.9 \\
Less than 5000 & 55 & 17.4 \\
5000-7000 & 81 & 25.6 \\
7000-10000 & 67 & 21.2 \\
10000-15000 & & \\
More than & 88 & 27.8 \\
15000 & &
\end{tabular}

Residency

In Trang

Outside Trang

61.1

Several time

First time

Second time

Third time

Fourth time

Trip purpose

Natural tour

Leisure

Eating

Diving

Duration

One day trip

Stay overnight

Two nights

More than 2

night

Involvement

Reduce plaster

used

Proper dispose

Purpose the

suggestion

Reduce plaster

used and

proper dispose

Proper dispose

and purpose

82

82
58

58
85

85
90

1

68

186

22

26

209

66.1

$56 \quad 17.7$

47

4

14.9

1.3 


\begin{tabular}{lcc}
$\begin{array}{l}\text { the suggestion } \\
\text { Reduce plaster } \\
\text { used and } \\
\text { purpose the } \\
\text { suggestion }\end{array}$ & 13 & \\
\hline Items & Number & Percent \\
\hline $\begin{array}{l}\text { Motivation } \\
\text { Commend }\end{array}$ & 40 & 12.7 \\
$\begin{array}{l}\text { People } \\
\text { commend }\end{array}$ & 17 & 5.4 \\
$\begin{array}{l}\text { Community } \\
\text { commend }\end{array}$ & 142 & 44.9 \\
Reward & 10 & 3.2 \\
Punishment & 174 & 55.1 \\
\hline
\end{tabular}

\section{B. Knowledge, Attitude and Behavior of Plastic Waste Reduction}

Table II indicated the level of knowledge, attitude and behavior for plastic use reduction of tourist. Most of tourist $(60.1 \%)$ has the poor knowledge of plastic waste reduction. The good attitude for plastic waste reduction was found in the more than $76 \%$ of tourist in this province. For plastic waste reduction behavior, $57.0 \%$ of tourist was good behavior. For statistical analysis (Table III), tourists who were high knowledge had a good behavior for plastic waste reduction. Multiple logistic regression analysis revealed that high knowledge tourist was 5.6 times more likely to good behavior for plastic use reduction (Adj. OR 5.676; 95\% CI: 3.36-9.58).
Among the reasons for the lack of behavior change are, influencing knowledge of environmental issues, but also enhancing visitor experiences and thus their satisfaction [16]. It has only been in recent years that the power wildlife tourism has to affect change and the assumption of attitudes leading to behavior change in this sector have been recognized, in particular that a general attitude about a thing has been proven in numerous studies to not lead to specific behaviors. Further, it is now recognized that interpretive and educational experiences provided to tourists will not change behaviors "unless a specific behavior is explicitly targeted and communication is designed to address attitudes relevant to that behavior" [17].

TABLE II: LEVEL OF KNOWLEDGE, ALLTITUdE AND BEHVIOR OF PLASTIC WASTE REDUCTION

\begin{tabular}{lcc}
\hline \hline Items & Number & Percent \\
\hline Knowledge & & \\
Poor & 190 & 60.1 \\
Good & 126 & 39.9 \\
Attitude & & \\
Poor & 74 & 23.4 \\
Good & 242 & 76.6 \\
Behavior & & \\
Poor & 136 & 43.0 \\
Good & 180 & 57.0 \\
\hline \hline
\end{tabular}

TABLE III: ASSOCIATION AND PREDICTION WITH PLASTIC WASTE REDUCTION

\begin{tabular}{|c|c|c|c|c|c|c|c|c|}
\hline \multirow{3}{*}{ Items } & \multicolumn{4}{|c|}{ Behavior level } & \multirow{3}{*}{ COR } & \multicolumn{2}{|c|}{$95 \% \mathrm{CI}$} & \multirow{3}{*}{$P$ value } \\
\hline & \multicolumn{2}{|c|}{ Poor } & \multicolumn{2}{|c|}{ Good } & & \multirow{2}{*}{ Lower } & \multirow{2}{*}{ Upper } & \\
\hline & $\mathrm{n}$ & $\%$ & $\mathrm{n}$ & $\%$ & & & & \\
\hline \multicolumn{9}{|l|}{ Age } \\
\hline \multicolumn{9}{|l|}{ Below 34} \\
\hline & 60 & 40.8 & 87 & 59.2 & 1 & & & \\
\hline Over 34 & 76 & 45.0 & 93 & 55.0 & 0.844 & 0.540 & 1.320 & 0.457 \\
\hline \multicolumn{9}{|l|}{ Sex } \\
\hline \multirow{2}{*}{$\begin{array}{l}\text { Male } \\
\text { Female }\end{array}$} & 65 & 42.5 & 88 & 57.5 & 1 & & & \\
\hline & 71 & 43.6 & 92 & 56.4 & 0.957 & 0.613 & 1.495 & 0.847 \\
\hline \multicolumn{9}{|l|}{ Education } \\
\hline Lower than bachelor & 86 & 43.0 & 114 & 57.0 & 1 & & & \\
\hline Bachelor and higher & 50 & 43.1 & 66 & 56.9 & 0.996 & 0.627 & 1.580 & 0.986 \\
\hline \multicolumn{9}{|l|}{ Status } \\
\hline Single & 62 & 49.2 & 64 & 50.8 & 1 & & & \\
\hline Couple & 74 & 38.9 & 116 & 61.1 & 1.519 & 0.963 & 2.394 & 0.072 \\
\hline \multicolumn{9}{|l|}{ Occupation } \\
\hline Regular income & 76 & 48.7 & 80 & 51.3 & 1 & & & \\
\hline Irregular income & 60 & 38.2 & 97 & 61.8 & 1.536 & 0.980 & 2.408 & 0.061 \\
\hline \multicolumn{9}{|l|}{ Level of Income } \\
\hline 10000 or less & 69 & 42.9 & 92 & 57.1 & 1 & & & \\
\hline More than 10000 & 67 & 43.2 & 88 & 56.8 & 0.985 & 0.631 & 1.538 & 0.947 \\
\hline \multicolumn{9}{|l|}{ Resident } \\
\hline In Trang & 86 & 44.6 & 107 & 55.4 & 0.852 & 0.539 & 1.348 & 0.494 \\
\hline Outside Trang & 50 & 40.7 & 73 & 59.3 & 1 & & & \\
\hline \multicolumn{9}{|l|}{ Number of visit } \\
\hline Several time & 28 & 48.3 & 30 & 51.7 & 1 & & & \\
\hline Few times & 69 & 39.2 & 107 & 60.8 & 1.281 & 0.773 & 2.124 & 0.337 \\
\hline \multicolumn{9}{|l|}{ Trip purpose } \\
\hline Leisure & 76 & 40.9 & 110 & 59.1 & 1.241 & 0.789 & 1.950 & 0.350 \\
\hline Other & 51 & 54.3 & 43 & 45.7 & 1 & & & \\
\hline \multicolumn{9}{|l|}{ Duration } \\
\hline One day trip & 90 & 43.1 & 119 & 56.9 & 0.997 & 0.632 & 1.596 & 0.990 \\
\hline More than one day & 46 & 43.0 & 61 & 57.0 & 1 & & & \\
\hline
\end{tabular}




\begin{tabular}{|c|c|c|c|c|c|c|c|c|}
\hline Yes & 118 & 43.2 & 155 & 56.8 & 0.946 & 0.493 & 1.814 & 0.867 \\
\hline No & 18 & 41.9 & 25 & 58.1 & 1 & & & \\
\hline \multicolumn{9}{|l|}{ Participation } \\
\hline Positive strategies & 57 & 40.1 & 85 & 59.9 & 1.24 & 0.798 & 1.943 & 0.348 \\
\hline Punishment & 79 & 45.4 & 95 & 54.6 & 1 & & & \\
\hline \multicolumn{9}{|l|}{ Knowledge } \\
\hline Poor & 111 & 58.4 & 79 & 41.6 & 1 & & & \\
\hline Good & 25 & 19.8 & 101 & 80.2 & 5.676 & 3.360 & 9.589 & $<0.001$ \\
\hline \multicolumn{9}{|l|}{ Attitude } \\
\hline \multirow{2}{*}{$\begin{array}{l}\text { Poor } \\
\text { Good }\end{array}$} & 32 & 43.2 & 42 & 56.8 & 1 & & & \\
\hline & 104 & 43.0 & 138 & 57.0 & 1.011 & 0.598 & 1.710 & 0.967 \\
\hline
\end{tabular}

It can be conclused that this study provides the foundation for high level of behavior for plastic waste reduction of tourist in Thailand. Hence, it confirms the strong perdictors of knowledge of plastic waste reduction with the behavior of plastic waste reduction among Thai tourists in the costal area of Trang provice, Thailand. The knowledge of plastic waste reduction ought to be promoted to increase of awareness among tourists for reducing plastic waste problem in the coastal area at early age. A greater emphasis must be placed on formulation and implementation of policies aimed at addressing the emerging problems of plastic waste in the costal area of Thailand.

\section{CONCLUSION}

The purpose of this study was to determine the level and predictor of behavior among Thai tourist for plastic waste reduction in the costal area of Trang province, Thailand. Five districts in the coastal area of Trang Province were included as the study area. The logistic regression and multiple logistic regressions were used to determine the association and the best predictor for plastic waste reduction among Thai tourists. The results performed that knowledge of plastic waste reduction were found to be the most significant predictors of good behavior.

\section{CONFLICT OF INTEREST}

The authors declare no conflict of interest.

\section{AUTHOR CONTRIBUTIONS}

Conceptualization, and methodology, C.R., ;data collection, P.S, T.T.S; data analysis, O.L.; writing, W.O.; funding acquisition, C.R.

\section{ACKNOWLEDGMENT}

This research was supported by National Research Council of Thailand.

\section{REFERENCES}

[1] PlasticsEurope. (2016). Plastics - The Facts 2016: An Analysis of European Plastics Production, Demand and Waste Data. [Online]. Available: http://www.plasticseurope.org

[2] L. Lebreton and A. Andrady, "Future scenarios of global plastic waste generation and disposal," Palgrav Communications, vol. 5, no. 1, p. 6, 2019

[3] A. L. Andrady, "Microplastics in the marine environment," Marine Pollution Bulleti, pp. 1596-1605, 2011.

[4] C. M. Rochman, M. A. Browne, B. S. Halpern, B. T. Hentschel, E. Hoh, H. K. Karapanagioti, L. M. Rios-Mendoza, H. Takada, S. Teh, and R. C.
Thompson, "Policy: Classify plastic waste as Hazardous," Nature, vol. 494, no. 7436, p. 169, 2013.

[5] J. A. Ivar, and M. F. Costa, "The present and future of Microplastic pollution in the marine environment," Environmemtal Pollution, vol. 185, pp. 352-364, 2014.

[6] B. Trotter et al., Scientific Report, 2019.

[7] P. G. Ryan, "A simple technique for counting marine debris at sea reveals steep litter gradients between the Straits of Malacca and the Bay of Bengal," Marine Pollution Bulletin, vol. 69, pp. 128-136, 2013.

[8] C. Slavin, A. Grage, and M. L. Campbell, "Linking social drivers of marine debris with actual marine debris on beaches," Marine Pollution Bulletin, vol. 64, pp. 580-1588, 2012.

[9] J. L. Lavers, "Exceptional and rapid accumulation of anthropogenic debris on one of the world's most remote and pristine islands," in Proc. the National Academy of Sciences, vol. 114, p. 6052, 2017.

[10] L. Lebreton, "Evidence that the Great Pacific Garbage Patch is rapidly accumulating Plastic," Scientific Report, vol. 8, no. 1, p. 2939

[11] National Statistic Office, Thailand, "Number of tourists in 2016," Bangkok, 2017.

[12] Trang Provincial Administrative Organization, "Solid waste situation of Trang Province," Provincial Administrative Organization, 2018.

[13] M. L. D. Silva, R. O. Castro, and A. S. Sales, "Marine debris on beaches of Arraial do Cabo, RJ, Brazil: An important coastal tourist destination," Marine Pollution Bulletin, vol. 130, pp. 153-158, 2018.

[14] F. J. Kuo and H. W. Huang, "Strategy for mitigation of marine debris:Analysis of sources and composition of marine debris in northern Taiwan," Marine Pollution Bulletin, vol. 83, pp. 70-78, 2014

[15] G. Pasternak, D. Zviely, and C. A. Ribic, "Sources, composition and spatial distribution of marine debris along the Mediterranean coast of Israel," Marine Pollution Bulletin, vol. 114, pp. 1036-1045, 2017

[16] J. Skibins, C. Hallo, L. Jeffrey, J. E. Sharp, and M. Robert, "Quantifying the role of viewing the Denali "Big 5" in visitor satisfaction and awareness: Conservation implications for flagship recognition and resource management," Human Dimensions of Wildlife, vol. 17, pp. 112-128, 2012.

[17] H. D. Stern and M. R. Powell. "Environmental education program evaluation in the new millennium: What do we measure and what have we learned?" Environmental Education Research, vol. 20, 2013.

Copyright $\odot 2020$ by the authors. This is an open access article distributed under the Creative Commons Attribution License which permits unrestricted use, distribution, and reproduction in any medium, provided the original work is properly cited (

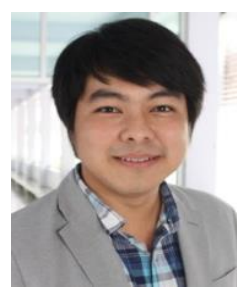

Weerawat Ounsaneha received his Ph.D. degree in environmental management from Prince of Songkla University, Thailand, in 2014 and was appointed to the lecturer in environmental science program at Faculty of Science and Technology, Valaya Alongkorn Rajabhat University under the Royal Patronage, Thailand.

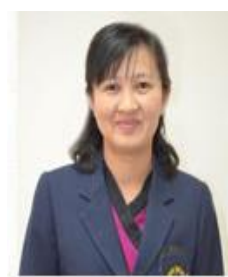

Orapin Laosee received her Ph.D. degree in Ph.D (public health), College of Public Health Science, Chulalongkorn University, Thailand in 2011 and now she was assistant professor in public health appointed to the Lecture of ASEAN Institute for Health Development, Mahidol University, Thailand. 


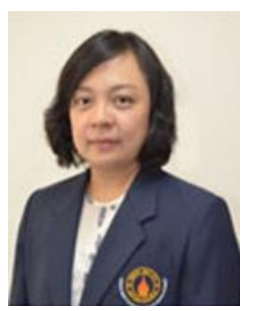

Thunwadee Tachapattaworakul Suksaroj received her Ph.D. degree in Dr.Sc.(industrial science and biological process: Food science) from Université Montpellier II, France, in 2006 and Now she was assistant professor in environmental technology appointed to the Lecture of ASEAN Institute for Health Development, Mahidol University, Thailand.

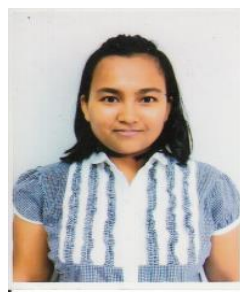

Pintip Srisamai received her M.Sc degree in environmental management from Prince of Songkla University, Thailand, in 2006 and was appointed to the environmentalist, professional level of Trang Provincial Administrative Organization, Trang, Thailand.

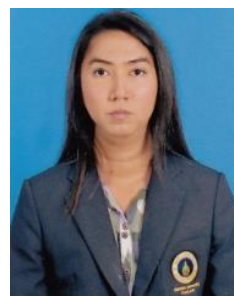

Cheerawit Rattanapan was appointed to the lecture of ASEAN Institute for Health Development, Mahidol University, Thailand in October, 2009 after completing a doctoral degree in biotechnology at Prince of Songkla University, Thailand. She has over 10 years of experience research in the environmental fields. Her current research interests focus on environmental biotechnology, environmental and occupational health, environmental management and sustainable development. She has published more than 50 technical papers in peer refereed journal and proceeding with a strong citation record. She has been a reviewer of several international journals in environmental areas. 